\title{
Effect of Germination on the Physical and Functional Properties of Brown Rice Flours
}

\author{
Naseerunnisa Mohmmed, Aparna Kuna1, Supta Sarkar², M.M. Azam³ , K. Lakshmi Prasanna
}

10.18805/ajdfr.DR-1799

\begin{abstract}
Background: Germinated brown rice (GBR) flour recently gained popularity due to its nutritional and health-promoting benefits and is being used as a functional ingredient in formulation of various food products, replacing rice flour. GBR is prepared by soaking brown rice (BR), more specifically, the embryo of brown rice in water to promote grain activation under controlled conditions.

Methods: Present study was aimed to develop the GBR flours of MTU 1010 and KNM 118 at various germination hours $(0,12,24,36$, 48 and 72 hours) and to study the effect of germination on the physical and functional properties of BR and GBR flours.

Result: Our findings revealed that germination showed significant variations in $I^{*}, a^{*}, b^{*}$ and $D E^{*}$ of $B R$ flours of both varieties. Germination significantly decreased the bulk density, tapped density, oil absorption capacity, water activity. Germination also considerably improved the water absorption capacity at 24 hours of germination and foaming capacity of MTU 1010 and KNM 118 GBR flours. BR flour had the least gelation concentration (LGC) of $8 \%$ and $6 \%$ which increased to $12 \%$ and $10 \%$ after $24 \mathrm{~h}$ germination in MTU 1010 and KNM 118 GBR flours, respectively.
\end{abstract}

Key words: Brown rice, Functional properties, Germinated brown rice flour, Physical properties.

\section{INTRODUCTION}

Health-conscious consumers always look for natural foods containing good nutritional and health properties, with ease of procurement, preparation and consumption. There has been an increasing demand for such foods. GBR and its flour is gaining prominence in East Asia for product development in the recent past. In India, GBR market is still nascent and needs research to study GBR flour properties with Indian rice varieties.

GBR is much healthier in contrast to normal brown rice, as it is richer in the essential nutritional components (vitamins, minerals, dietary fibres, essential amino acids) and contains more bioactive components such as gammaaminobutyric acid (Wu et al., 2013). Compared to brown rice, dried GBR offers an excellent appearance, improved shelf life, handling ease and good sensory attributes. Germination process activates hydrolytic enzymes such as $\alpha$-amylase, protease and lipase, resulting in the degradation of starch, protein and lipids, respectively (Wichamanee and Teerarat, 2012), resulting in enzymatic modification of starch that affects pasting properties of GBR flour and when used in baking, improves the bread quality when substituted for wheat flour. GBR is considered a gluten-free grain characterized by an excellent nutrient profile and bioactive compounds (Caceres et al., 2014). GBR can become a valuable processing ingredient for developing various healthy product formulations such as snack foods, extruded GBR snacks, infant foods, baked foods and beverages. During the last decade, about 49 items related to the use of GBR in food formulations have been patented (Patil and Khan, 2011) in Asian countries, indicating the importance of GBR flour in food formulations.

The application of GBR flour in the preparation of various food products from different sources in food systems
${ }^{1}$ Ministry of Food Processing Industries, Quality Control Laboratory, Professor Jayashankar Telangana State Agricultural University, Hyderabad-500 030, Telangana, India.

2Department of Foods and Nutrition, College of Community Nutrition, Professor Jayashankar Telangana State Agricultural University, Hyderabad-500 030, Telangana, India.

${ }^{3}$ Indian Council of Agricultural Research, Indian Institute of Rice Research, Rajendranagar-500 030, Telangana, India.

Corresponding Author: Naseerunnisa Mohmmed, Post Graduate and Research Centre, Professor Jayashankar Telangana State Agricultural University, Hyderabad-500 030, Telangana, India. Email: naseemapandu@gmail.com

How to cite this article: Mohmmed, N., Kuna, A., Sarkar, S., Azam, M.M. and Prasanna, K.L. (2022). Effect of Germination on the Physical and Functional Properties of Brown Rice Flours. Asian Journal of Dairy and Food Research. DOI: 10.18805/ajdfr.DR-1799. Submitted: 19-08-2021 Accepted: 14-02-2022 Online: 04-03-2022

depends to a greater extent on their physiochemical and functional properties (Chinma et al., 2009). Market value, utilization and consumer preferences of GBR flour are indicated by their physicochemical properties. At the same time, the behaviour of starch, protein and other components in foods during processing, storage and preparation as they affect food quality and acceptability is governed by their functional properties (Falade and Christopher, 2014). Therefore, the functionality of flours prepared from germinated grains is desirable for their consumption as new raw material. To date, there is a dearth of information available on the effect of germination conditions on the functional characteristics of GBR flour. Therefore, the objective of the present study was to investigate the impact of germination conditions $(0,12,24,36,48,72 \mathrm{~h})$ on selected 
physical and functional properties of BR flour prepared from different germination conditions for the development of specialty food products with potential health benefits.

\section{MATERIALS AND METHODS}

\section{Procurement of rice samples}

Brown rice samples (MTU 1010 and KNM 118 varieties) were collected from Rice Research Centre, Rajendranagar, Hyderabad. Chemicals and required consumables were utilized from PGRC and MFPI-Quality Control Laboratory, PJTSAU, Rajendranagar, Hyderabad. Other required ingredients were procured from local markets. The experiments were conducted during the year 2020-2021.

Processing of GBR was done according to Cornejo et al. (2015). MTU 1010 and KNM 118 rice varieties were subjected to soaking for 12 hours at $28 \pm 2^{\circ} \mathrm{C}$, followed by incubation at $28 \pm 2^{\circ} \mathrm{C}$ for different time intervals of $12,24,36$, 48 and 72 hours. GBR samples were dried in a tray dryer at $50 \pm 3^{\circ} \mathrm{C}$ until moisture content was less than $12 \%$. Colour estimation was done for dried GBR flours of MTU 1010 and KNM 118 as perAOAC 1998 method. Bulk density and tapped density were determined by methods described by Stojceska et al., (2008) and Narayana and Narasinga, (1982).

\section{Bulk density and tapped density}

A $100 \mathrm{ml}$ measuring cylinder was taken and weighed $\left(\mathrm{W}_{1}\right)$. GBR flour sample was filled into the measuring cylinder up to the $100 \mathrm{ml}$ mark. The weight of the sample flour filled into the measuring cylinder was noted $\left(\mathrm{W}_{2}\right)$ and the process was repeated thrice. For tapped density, after weighing samples $\left(\mathrm{W}_{1}\right)$ in $100 \mathrm{ml}$ graduated measuring cylinder, it was gently tapped to eliminate spaces between the sample and reweighed $\left(\mathrm{W}_{2}\right)$ in triplicates. The unit of measurement was expressed in $\mathrm{g} / \mathrm{ml}$.

$$
\text { Bulk and tapped density }=\frac{\left(\mathrm{W}_{2}-\mathrm{W}_{1}\right) \text { in } \mathrm{g}}{\text { Volume }(\mathrm{ml})}
$$

\section{Water and oil absorption capacity (WAC and OAC)} (Suresh Chandra and Samsher, 2013)

Two grams of sample was suspended in water at room temperature for $30 \mathrm{~min}$ with gentle stirring and centrifuged for $15 \mathrm{~min}$ at $3000 \mathrm{rpm}$ to obtain clear supernatant, which was decanted into an evaporating dish of known weight. WAC was the weight of suspension obtained after removal of supernatant per unit of original weight. For oil absorption, $10 \mathrm{ml}$ refined sunflower oil was used. The unit of measurement was presented as \%.

$$
\text { WAC and OAC }(\%)=\frac{\text { Weight of the sediment }}{\text { Weight of the dry solids }} \times 100
$$

\section{Foaming capacity (FC\%)}

The FC (\%) was determined as described by Narayana and Narasinga (1982). One gram of BR and GBR flour samples were added to $50 \mathrm{~mL}$ distilled water at $30 \pm 2^{\circ} \mathrm{C}$ in a graduated cylinder. The suspension was mixed and shaken for $5 \mathrm{~min}$ to foam. The volume of foam at $30 \mathrm{sec}$ after whipping was expressed as foam capacity (\%) using the formula:
The unit of measurement was \%.

Foaming capacity $(\mathrm{FC} \%)=$

$$
\frac{\text { Vol. after whipping }- \text { Vol. before whipping }}{\text { Vol. before whipping }} \times 100
$$

Least gelation concentration (LGC)

Least gelation concentration was estimated following the methods of Moongngarm et al., 2014). BR and GBR flour suspensions in $5 \mathrm{ml}$ distilled water were prepared to obtain $2 \%, 4 \%, 6 \%, 8 \%, 10 \%, 12 \%, 14 \%, 16 \%, 18 \%$ and $20 \%(\mathrm{w} / \mathrm{v})$ suspension concentrations. The test tubes containing flour suspensions were heated in boiling water for $1 \mathrm{~h}$ and then cooled down under running tap water for an hour. The least gelation concentrations were determined as the concentration at which the sample from the inverted test tubes did not fall or slip.

\section{Water activity $\left(a_{w}\right)$}

Water activity was determined following the methodology of Abramovic et al., (2008). Around $20^{\circ} \mathrm{C}$ using advanced water activity meter (NOVASINA). The equipment was calibrated with saturated salt solution. $2.0 \mathrm{~g}$ of sample was weighed and placed in the instrument till constant reading was obtained and values were noted. For each determination three replicates were carried out and the average value was calculated.

\section{Statistical analysis}

The experiments were performed in triplicates. The generated data was subjected to Analysis of Variance (ANOVA) using SPSS version 23 (SPSS, IBM, Chicago USA). The values obtained were presented as mean \pm standard deviation of parallel measurements.

\section{RESULTS AND DISCUSSION}

The colour attributes $\left(I^{*}, a^{*}, b^{*}\right.$ and $\left.D E^{*}\right)$ of the BR and GBR flour samples were significantly different $(P \leq 0.005)$ from each other, as given in Table 1 . The $\mathrm{I}^{*}$ values of $\mathrm{BR}$ and GBR flour of MTU 1010 and KNM 118 were found to be in the range of $77.39 \pm 0.00$ to $88.32 \pm 0.02$ and $80.82 \pm 0.02$ to $86.71 \pm 0.01$, respectively. It was observed that $I^{*}$ value decreased with an increase in germination. The $a^{*}$ values of BR and GBR flour of MTU 1010 and KNM 118 were found to be in the range of $2.58 \pm 0.01$ to $3.64 \pm 0.04$ and $3.30 \pm 0.03$ to $4.27 \pm 0.02$, respectively. The $b^{*}$ values of $B R$ and GBR flour of MTU 1010 and KNM 118 was found to be in the range of $15.04 \pm 0.01$ to $17.47 \pm 0.02$ and $15.93 \pm 0.00$ to $19.53 \pm 0.00$, respectively. The $D E^{*}$ values of $B R$ and $G B R$ flours of MTU 1010 and KNM 118 were found to be in the range of $36.02 \pm 0.01$ to $44.63 \pm 0.01$ and $40.35 \pm 0.00$ to $44.13 \pm 0.01$, respectively.

The results obtained showed that the germination process significantly affects the colour of the flour of BR (MTU 1010 and KNM 118). This could be due to enzymatic activities during the germination process, which results in the hydrolysis of starch and protein into simple sugar and amino acids, respectively. On the other hand, the sugar and 
amino acids can induce the Maillard reaction (Islam et al., 2012), responsible for lightness and yellowness values in GBR. The colour is an important performance characteristic of rice flour affecting the appearance of finished products since rice flour generally serves as the foundational ingredient for rice-based products. Based on the results obtained, though the BR flour was whiter (higher $I^{*}$ value) than the GBR flour, it can be utilized in product development without significantly impacting on the finished product colour.

The Bulk density of two varieties of $B R$ at various germination hours are listed in Fig 1 and 2. It was observed that germination significantly $(p \leq 0.05)$ decreased the bulk density in MTU 1010 and KNM 118 varieties. The bulk density of BR and GBR flours of MTU 1010 and KNM 118 was found to be in the range of $0.45 \pm 0.00 \mathrm{~g} / \mathrm{ml}$ to $0.62 \pm 0.00 \mathrm{~g} / \mathrm{ml}$ and $0.50 \pm 0.01 \mathrm{~g} / \mathrm{ml}$ to $0.61 \pm 0.01 \mathrm{~g} / \mathrm{ml}$, respectively. Bulk density was highest in raw BR of MTU $1010(0.62 \pm 0.00 \mathrm{~g} / \mathrm{ml})$ and KNM $118(0.61 \pm 0.01 \mathrm{~g} / \mathrm{ml})$. Similar results by Moongngarm et al. (2014) reported that germination significantly decreased the bulk density of BR flour in Yellow-11, Chianat-1, Khao Dok Mali-105 (KDML-105) and RD-6 varieties.

As the germination time increased, tapped density decreased. At $72 \mathrm{~h}$ of germination, the lowest tapped density

Table 1: Colour of BR and GBR flour of MTU 1010 and KNM 118.

\begin{tabular}{|c|c|c|c|c|}
\hline Germination hours & Colour L* & Colour $a^{*}$ & Colour b* & Colour DE* \\
\hline \multicolumn{5}{|l|}{ MTU 1010} \\
\hline 0 & $83.03 \pm 0.01^{\mathrm{c}}$ & $3.16 \pm 0.03^{c}$ & $16.48 \pm 0.01^{c}$ & $40.75 \pm 0.00^{c}$ \\
\hline 12 & $87.65 \pm 0.01^{d}$ & $3.46 \pm 0.02^{\mathrm{d}}$ & $17.13 \pm 0.03^{d}$ & $43.73 \pm 0.03^{d}$ \\
\hline 24 & $88.32 \pm 0.02^{\mathrm{e}}$ & $3.64 \pm 0.04^{\mathrm{e}}$ & $17.47 \pm 0.02^{f}$ & $44.26 \pm 0.02 \mathrm{e}$ \\
\hline 36 & $87.57 \pm 0.16^{d}$ & $3.45 \pm 0.01^{d}$ & $17.31 \pm 0.01^{\mathrm{e}}$ & $44.63 \pm 0.01^{f}$ \\
\hline 48 & $77.39 \pm 0.00^{\mathrm{a}}$ & $2.58 \pm 0.01^{a}$ & $15.65 \pm 0.04^{b}$ & $36.02 \pm 0.01^{a}$ \\
\hline 72 & $80.51 \pm 0.01^{b}$ & $2.95 \pm 0.04^{b}$ & $15.04 \pm 0.01^{\mathrm{a}}$ & $38.65 \pm 0.02^{b}$ \\
\hline Grand mean & 84.07 & 3.20 & 16.51 & 41.33 \\
\hline $\mathrm{SE}$ of mean & 0.99 & 0.08 & 0.21 & 0.77 \\
\hline C.D & 0.12 & 0.05 & 0.04 & 0.02 \\
\hline CV\% & 0.08 & 0.87 & 0.14 & 0.02 \\
\hline \multicolumn{5}{|l|}{ KNM 118} \\
\hline 0 & $84.16 \pm 0.01^{c}$ & $3.85 \pm 0.04^{a}$ & $15.93 \pm 0.00^{\mathrm{a}}$ & $41.26 \pm 0.04^{b}$ \\
\hline 12 & $84.88 \pm 0.02^{d}$ & $3.62 \pm 0.02^{\mathrm{b}}$ & $16.26 \pm 0.03^{b}$ & $42.07 \pm 0.01^{c}$ \\
\hline 24 & $86.71 \pm 0.01^{f}$ & $3.87 \pm 0.02^{f}$ & $19.53 \pm 0.00^{f}$ & $44.13 \pm 0.01^{\mathrm{e}}$ \\
\hline 36 & $86.24 \pm 0.04^{e}$ & $3.30 \pm 0.03^{c}$ & $16.55 \pm 0.03^{c}$ & $43.15 \pm 0.04^{d}$ \\
\hline 48 & $81.47 \pm 0.01^{b}$ & $3.72 \pm 0.03^{e}$ & $18.17 \pm 0.03^{e}$ & $40.35 \pm 0.00^{\mathrm{a}}$ \\
\hline 72 & $80.82 \pm 0.02^{\mathrm{a}}$ & $4.27 \pm 0.02^{\mathrm{d}}$ & $17.04 \pm 0.02^{\mathrm{d}}$ & $40.37 \pm 0.02^{\mathrm{a}}$ \\
\hline Grand mean & 84.04 & 3.77 & 17.24 & 41.88 \\
\hline $\mathrm{SE}$ of mean & 0.53 & 0.07 & 0.30 & 0.33 \\
\hline C.D & 0.03 & 0.04 & 0.04 & 0.04 \\
\hline CV\% & 0.02 & 0.58 & 0.13 & 0.05 \\
\hline
\end{tabular}

Note: Values are expressed as mean \pm standard deviation of three determinations. Means within the same column followed by a common superscript do not differ significantly at $(p<0.05)$. $L^{*}$ (whiteness/brightness), $a^{*}$ (redness/greenness), $b^{*}$ (yellowness/blueness) and $D E^{*}$ (Total colour difference).

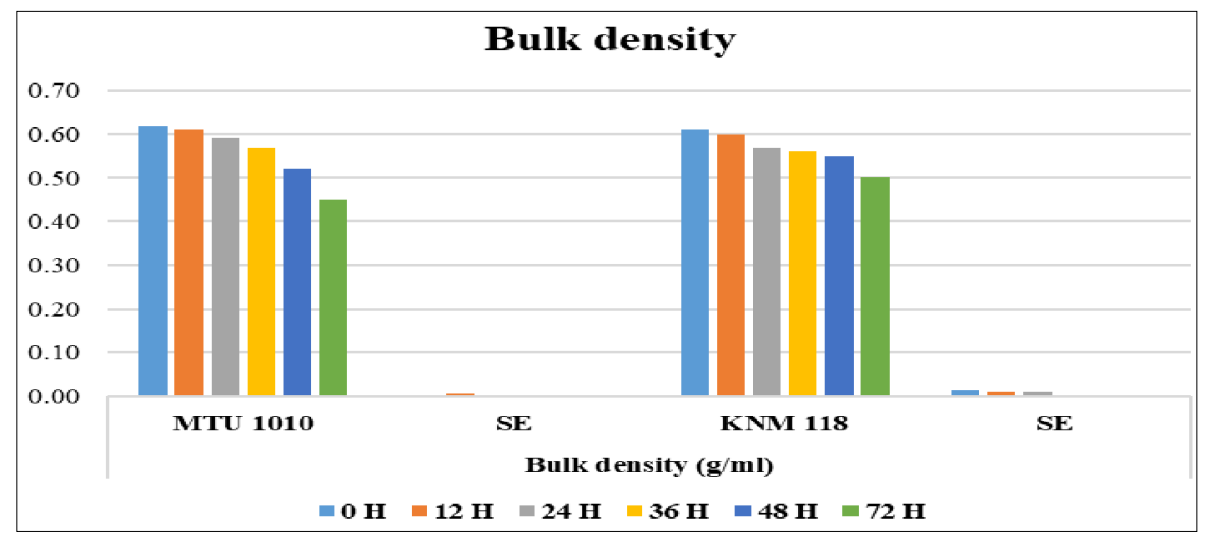

Fig 1: Bulk density $(\mathrm{g} / \mathrm{ml})$ of two $B R$ varieties at various germination hours. Note: Values are expressed as mean \pm standard error of three determinations. 
was recorded in MTU 1010 and KNM $118(0.61 \pm 0.00 \mathrm{~g} / \mathrm{ml}$ and $0.67 \pm 0.01 \mathrm{~g} / \mathrm{ml}$ ), respectively as shown in Figure 2. It was observed that germination led to a significant $(p \leq 0.05)$ reduction in the tapped density of MTU 1010 and KNM 118 samples at 36,48 and $72 \mathrm{~h}$ of germination. In contrast, the decrease in tapped density was non-significant at 0,12 and $24 \mathrm{~h}$ of germination, respectively. Lower tapped density recorded for GBR compared to BR was due to the smoother texture of GBR, which made it more compact compared to BR, as observed by Bolarinwa and Muhammad (2019). Tapped density and bulk density can be used to measure anatomy and packing for transportation and storage (Singh and Goswami, 1996).

The water absorption capacity of two varieties of BR at various germination hours is listed in Table 2. WAC of BR and GBR flours of MTU 1010 and KNM 118 at various germination hours was found to be in the range of $105.13 \pm 0.46 \%$ to $106.67 \pm 0.58 \%$ and $110.67 \pm 0.58 \%$ to $113.67 \pm 0.58 \%$, respectively. The WAC was highest in MTU 1010 and KNM 118 at $24 \mathrm{~h}$ germination, i.e., $106.67 \pm 0.58 \%$ and $113.67 \pm 0.58 \%$, respectively. Other studies also reported that the water absorption capacities of cowpea, green gram, lentil and Bengal gram were improved by germination
(Ghavidel and Prakash, 2006; Padmashree et al., 1987). Generally, flour with high water absorption produces stiff bread dough with reduced stickiness.

Oil absorption capacity (OAC) of two BR varieties at various germination hours is listed in Table 2. OAC of BR and GBR flours of MTU 1010 and KNM 118 varieties at various germination hours was found to be in the range of $105.67 \pm 0.58 \%$ to $108.67 \pm 0.58 \%$ and $105.33 \pm 0.58 \%$ to $108.67 \pm 0.58 \%$, respectively. The lowest OAC value was observed at $72 \mathrm{~h}$ germination in MTU 1010 (105.67 $\pm 0.58 \%)$ and KNM $118(105.33 \pm 0.58 \%)$, respectively. Akubor and Chukwu (1999) also reported an increase in OAC for germinated millet flour. OAC of GBR flour suggests that in the formulation of foods where an oil holding capacity is an essential consideration, such as bakery products, this flour would be useful and such flours can be incorporated in batters used in the preparation of savoury fried foods (Singh and Sharma, 2015).

The foaming capacity (FC) of a protein refers to the amount of interfacial area that can be created by the protein (Fennama, 1996). It was observed that the least $\mathrm{FC}$ value $(1.90 \pm 0.02 \%, 1.88 \pm 0.04 \%)$ was seen in raw BR samples and the highest FC value $(9.59 \pm 0.01 \%, 8.58 \pm 0.11 \%)$ was

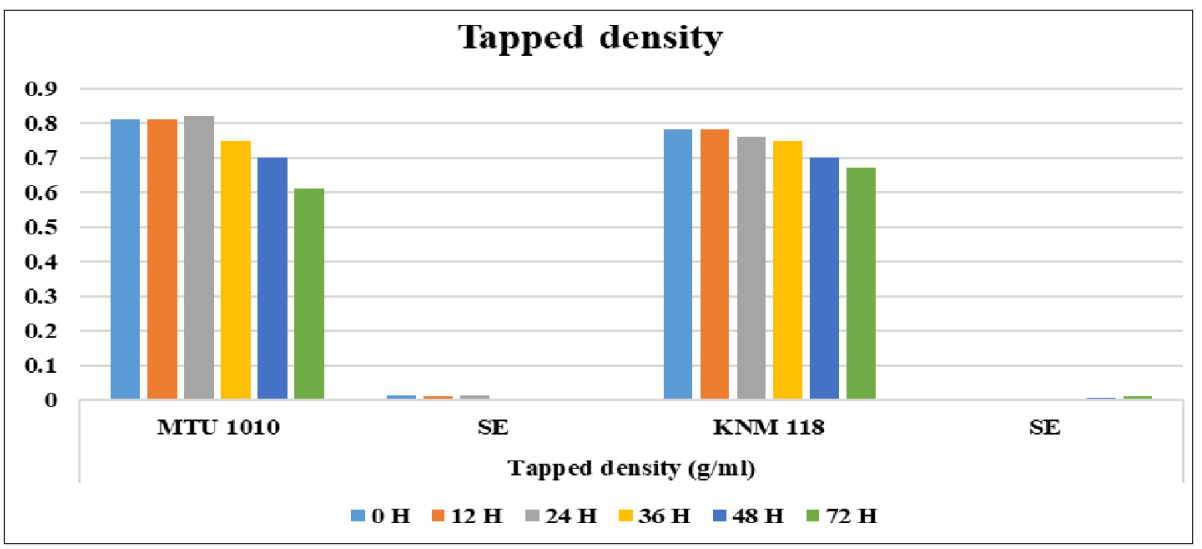

Fig 2: Tapped density $(\mathrm{g} / \mathrm{ml})$ of two $\mathrm{BR}$ varieties at various germination hours. Note: Values are expressed as mean \pm standard error of three determinations.

Table 2: Functional properties of BR and GBR varieties (MTU 1010 and KNM 118).

\begin{tabular}{|c|c|c|c|c|c|c|}
\hline \multirow{2}{*}{ Germination hours } & \multicolumn{2}{|c|}{ Water absorption capacity (\%) } & \multicolumn{2}{|c|}{ Oil absorption capacity (\%) } & \multicolumn{2}{|c|}{ Foaming capacity (\%) } \\
\hline & MTU 1010 & KNM 118 & MTU 1010 & KNM 118 & MTU 1010 & KNM 118 \\
\hline 0 & $105.47 \pm 0.58^{a}$ & $112.67 \pm 0.58^{c}$ & $108.67 \pm 0.58^{c}$ & $108.67 \pm 0.58^{b}$ & $1.90 \pm 0.02^{\mathrm{a}}$ & $1.88 \pm 0.04^{\mathrm{a}}$ \\
\hline 12 & $105.63 \pm 0.29^{a}$ & $112.67 \pm 0.58^{c}$ & $107.67 \pm 0.58^{\mathrm{bc}}$ & $108.33 \pm 0.58^{b}$ & $3.68 \pm 0.14^{b}$ & $1.92 \pm 0.04^{a}$ \\
\hline 24 & $106.67 \pm 0.58^{b}$ & $113.67 \pm 0.58^{d}$ & $107.33 \pm 0.58^{b}$ & $108.12 \pm 0.58^{b}$ & $7.64 \pm 0.06^{c}$ & $3.74 \pm 0.08^{b}$ \\
\hline 36 & $105.27 \pm 0.58^{a}$ & $112.67 \pm 0.58^{c}$ & $107.67 \pm 0.58^{b}$ & $108.33 \pm 0.58^{b}$ & $7.59 \pm 0.08^{c}$ & $7.60 \pm 0.09^{c}$ \\
\hline 48 & $105.13 \pm 0.46^{a}$ & $111.67 \pm 0.58^{b}$ & $107.33 \pm 0.58^{b}$ & $108.33 \pm 0.58^{b}$ & $9.56 \pm 0.02^{d}$ & $7.63 \pm 0.21^{c}$ \\
\hline 72 & $105.67 \pm 0.58^{a}$ & $110.67 \pm 0.58^{a}$ & $105.67 \pm 0.58^{a}$ & $105.33 \pm 0.58^{a}$ & $9.59 \pm 0.01^{d}$ & $8.58 \pm 0.11^{d}$ \\
\hline Grand mean & 105.64 & 112.33 & 107.39 & 108.05 & 6.66 & 5.22 \\
\hline SE of mean & 0.15 & 0.25 & 0.24 & 0.32 & 0.70 & 0.67 \\
\hline C.D & 0.90 & 0.74 & 1.10 & 1.03 & 0.07 & 0.15 \\
\hline $\mathrm{CV}(\%)$ & $0.47 \%$ & $0.36 \%$ & $0.56 \%$ & $0.52 \%$ & $0.62 \%$ & $1.66 \%$ \\
\hline
\end{tabular}

Note: Values are expressed as mean \pm standard deviation of three determinations.

Means within the same column followed by a common letter do not significantly differ at $p \leq 0.05$. 
Table 3: Least gelation Concentration of MTU 1010 and KNM 118 Varieties.

\begin{tabular}{|c|c|c|c|c|c|c|c|c|c|c|c|c|}
\hline \multirow{2}{*}{$\begin{array}{l}\text { Flour } \\
\text { concentration } \\
(\% \mathrm{w} / \mathrm{v})\end{array}$} & \multicolumn{7}{|c|}{ MTU 1010 GBR Flour } & \multicolumn{5}{|c|}{ KNM 118 GBR Flour } \\
\hline & $\mathrm{Oh}$ & $12 \mathrm{~h}$ & $24 \mathrm{~h}$ & $36 \mathrm{~h}$ & $48 \mathrm{~h}$ & $72 \mathrm{~h}$ & $\mathrm{Oh}$ & $12 \mathrm{~h}$ & $24 \mathrm{~h}$ & $36 \mathrm{~h}$ & $48 \mathrm{~h}$ & $72 \mathrm{~h}$ \\
\hline $2 \%$ & - & - & - & - & - & - & - & - & - & - & - & - \\
\hline $4 \%$ & - & - & - & - & - & - & - & - & - & - & - & - \\
\hline $6 \%$ & \pm & \pm & & - & - & - & + & - & - & - & - & - \\
\hline $8 \%$ & + & + & - & - & - & - & + & \pm & \pm & - & - & - \\
\hline $10 \%$ & + & + & \pm & - & - & - & + & + & + & - & - & - \\
\hline $12 \%$ & + & + & + & - & - & - & + & + & + & - & - & - \\
\hline $14 \%$ & + & + & + & - & - & - & + & + & + & - & - & - \\
\hline $16 \%$ & + & + & + & - & - & - & + & + & + & - & - & - \\
\hline $18 \%$ & + & + & + & - & - & - & + & + & + & \pm & - & - \\
\hline $20 \%$ & + & + & + & \pm & - & - & + & + & + & + & - & - \\
\hline
\end{tabular}

Note: The least gelation concentration of germinated rice flour compared with ungerminated rice flour $(-=$ not gelled; $\pm=$ slightly gelled; $+=$ gelled).

Table 4: Water activity of two BR varieties at various germination hours.

\begin{tabular}{lcc}
\hline Germination hours & MTU1010 & KNM118 \\
\hline 0 & $0.46 \pm 0.00^{\mathrm{f}}$ & $0.48 \pm 0.01^{\mathrm{d}}$ \\
12 & $0.36 \pm 0.00^{\mathrm{c}}$ & $0.38 \pm 0.01^{\mathrm{c}}$ \\
24 & $0.32 \pm 0.01^{\mathrm{a}}$ & $0.32 \pm 0.00^{\mathrm{a}}$ \\
36 & $0.34 \pm 0.00^{\mathrm{b}}$ & $0.34 \pm 0.01^{\mathrm{b}}$ \\
48 & $0.39 \pm 0.00^{\mathrm{d}}$ & $0.38 \pm 0.00^{\mathrm{c}}$ \\
72 & $0.40 \pm 0.00^{\mathrm{e}}$ & $0.38 \pm 0.00^{\mathrm{c}}$ \\
Grand mean & 0.37 & 0.38 \\
SE of mean & 0.01 & 0.01 \\
C.D & 0.00 & 0.00 \\
CV\% & $0.62 \%$ & $0.78 \%$
\end{tabular}

Note: Values are expressed as mean \pm standard deviation of three determinations.

Means within the same column followed by a common letter do not significantly differ at $p \leq 0.05$.

seen in $72 \mathrm{~h}$ of germination in MTU 1010 and KNM 118 varieties, respectively as given in Table 2 . The results indicate that the germination significantly $(p<0.05)$ increased the foaming capacity of GBR flours. This may be due to the the number of solubilised proteins increased during germination, resulting in improved foaming capacity (Belitz and Grosch, 1999). Germinated flours with high FC may find application in development of various gluten-free products.

LGC of BR and GBR flours at various germination hours was carried out from $2 \%$ to $20 \%$ flour concentrations which revealed no gel formation at $2 \%$ in MTU 1010 and KNM 118, as given in Table 3. Gel formation was observed in GBR samples (24 h germination) of MTU 1010 and KNM 118 at $12 \%$ and $10 \%$ flour concentration, respectively. There was no gel formation in 48 and $72 \mathrm{~h}$ germinated GBR's of both varieties up to $20 \%$ flour concentration. It was observed that increased germination time led to decreased gel formation in both the varieties. Germination may break down the rice proteins and thus cause more denaturation and aggregation when heated than in the ungerminated rice flour (Moongngarm et al., 2014). The variation observed in the LGC was associated with quantity and type of protein, nonprotein components like starch and lipids that make up the flour and interaction between these components that may have a significant role on functional properties (Chinma et al., 2009; Sathe and Salunkhe, 1981). Flours with the highest LGC can be effectively used to prepare weaning foods, health mixes, porridge mixes with desirable sensory properties.

The $a_{w}$ of MTU 1010 and KNM 118 of BR and GBR flours was found to be in the range of $0.32 \pm 0.01$ to $0.46 \pm 0.00$ and $0.32 \pm 0.00$ to $0.48 \pm 0.01$, respectively, as mentioned in Table 4. Compared to BR flour, significantly decreased $(p \leq 0.05) a_{w}$ was observed in GBR flours of MTU 1010 and KNM 118 varieties. This might be due to the production of hydrophilic molecules during enzymatic degradation that occurred during the germination process. Hydrophilic molecules bind with water and cause less free water in GBR flours (Serin et al., 2018). The obtained $a_{w}$ values indicate longer shelf life and better keeping quality of the GBR flours developed and hence can be used in various food formulations.

\section{CONCLUSION}

Germination hours had a significant $(p<0.05)$ effect on the physical and functional properties of GBR flour, as was confirmed from the results obtained in the study. As the germination time progressed, the OAC decreased due to alteration in starch structure by enzymes, which finds its application in the preparation of gluten-free products. A significant decrease in bulk density, tapped density and water activity was observed in GBR flour compared to BR flour. Foaming capacity enhanced as the germination time increased owing to an increase in the protein solubility. An increase in the gel consistency and concentration finds the application of GBR flour in the preparation of weaning food mixes and porridge mixes for infants. Various food formulations using GBR flours can also be developed to 
meet the requirements of different subgroups of consumers, such as elders, children, pregnant women and individuals with risks for various chronic metabolic disorders. Also, public education on the health benefits of GBR based food products compared to rice-based products should be promoted for enhanced production and consumption of GBR, owing to their health benefits.

\section{Declarations}

\section{Funding}

The research was conducted as a part of M.Sc Student Research work, supported by Professor Jayashankar Telangana State Agricultural University, Hyderabad, India.

\section{Conflict of interest}

The authors report no conflicts of interest. The authors alone are responsible for the content and writing of the paper.

\section{Consent for publication}

The authors alone are responsible for the content and writing of the paper and give full consent for publication of the manuscript.

\section{Availability of data and material}

Entire data is available in the student academic repository and the laboratories where the experiment was conducted. production and consumption of GBR, owing to their health benefits.

\section{REFERENCES}

Abramovic, H., Jamnik, M., Burkan, L. and Kac, M. (2008). Water activity and water content in Slovenian honeys. Food Control. 19(11): 1086-1090.

Akubor, P.I. and Chukwu, J.K. (1999). Proximate composition and elected functional properties of fermented and unfermented African oil bean (Pentaclethra macrophylla) seed flour. Plant Foods for Human Nutrition. 54: 227-238.

AOAC. (1998). Official Methods of Analysis. In: Association of Official Analytical Chemists. [Horwitz, W.(ed.)], (13 ${ }^{\text {th }}$ Edition).

Belitz, H.D. and Grosch, W. (1999). Food Chemistry (2 $2^{\text {nd }}$ ed.). Berlin: Springer.

Bolarinwa, I.F and Muhammad, K. (2019). Functional properties, antioxidant activities and storage stability of cookies from GBR and rice-potato starch composite flour. Pertanika Journal of Tropical Agricultural Science. 42(2).

Caceres, P.J., Martínez-Villaluenga, C., Amigo, L. and Frias, J. (2014). Maximising the phytochemical content and antioxidant activity of Ecuadorian BR sprouts through optimal germination conditions. Food Chemistry. 152: 407-414.

Chinma, CE., Adewuyi, O. and Abu, JO. (2009). Effect of germination on the chemical, functional and pasting properties of flour from brown and yellow varieties of tigernut (Cyperus esculentus). Food Research International. 42: 1004-1009.

Cornejo, F., Caceres, P.J., Martínez-Villaluenga, C., Rosell, C.M. and Frias, J. (2015). Effects of germination on the nutritive value and bioactive compounds of BR breads. Food Chemistry. 173: 298-304.
Falade, K.O. and Christopher, A.S. (2014). Physical, functional pasting and thermal properties of flours and starches of six Nigerian rice cultivars. Food Hydrocolloids. 39: 41-50.

Fennama, R.O. (1996). Marcel Dekker Inc. New York, Basel, Hong Kong. Food Chemistry. (3rd ed). 36-39.

Ghavidel, R.A., Prakash, J. (2006). Effect of germination and dehulling on functional properties of legume flours. Journal of the Science of Food and Agriculture. 86: 11891195.

Islam, M.Z., Taneya, M.L.J., Shams-Ud-Din, M., Syduzzaman, M. and Hoque, M. (2012). Physicochemical and functional properties of BR (Oryza sativa) and wheat (Triticum aestivum) flour and quality of composite biscuit made thereof. Scientific Journal of Krishi Foundations. 10(2): 20-28.

Moongngarm, A., Moontree, T., Deedpinrum, P. and Padtong, K. (2014). Functional properties of brown rice flour as affected by germination. APCBEE procedia. 8: 41-46.

Narayana, K. and Narasinga, M.S.R. (1982). Functional properties of raw and heat processed winged bean (Psophocarpus tetragonolobus) flour. Journal of Food Science. 47(5): 1534-1538.

Padmashree, T.S., Vijayalakshmi, L., Puttaraj, S. (1987). Effect of traditional processing on the functional properties of Cowpea (Vigna unguiculata) flour. Journal of Food Science and Technology. 24: 221-225.

Patil, S.B. and Khan, M.K. (2011). Germinated brown rice as a value-added rice product: A Review. Journal of Food Science and Technology. 48(6): 661-667.

Sathe, S.K. and Salunkhe, D.K. (1981). Functional properties of great northern bean proteins: Emulsion, foaming, viscosity and gelation properties. Journal of Food Science. 46: 71-75.

Serin, S., Turhan, K.N and Turhan, M. (2018). Correlation between water activity and moisture content of Turkish flower and pine honeys. Food Science and Technology. 38(2): 238-243.

Singh, A. and Sharma, S. (2015). Bioactive components and functional properties of biologically activated cereal grains: A Bibliographic Review. Critical Reviews in Food Science and Nutrition.

Singh, K.K. and Goswami, T.K. (1996). Physical properties of cumin seed. Journal of Agricultural Engineering Research. 64(2): 93-98.

Stojceska, V., Ainsworth, P., Andrew, P., Esra, I. and Senol, I. (2008). Cauliflower by- products as a new source of dietary fibre, antioxidants and proteins in cereal based ready to eat expanded snacks. Journal of Food Engineering. 87: 554563.

Suresh Chandra and Samsher (2013). Assessment of functional properties of different flours. African Journal of Agricultural Research. 8(38): 4849-4852.

Wichamanee, Y. and Teerarat, I. (2012). Production of germinated red jasmine brown rice and its physicochemical properties. International Food Research Journal. 19(4): 1649-1654.

Wu, F., Chen, H., Yang, N., Wang, J., Duan, X., Jin, Z., et al. (2013). Effect of germination time on physicochemical properties of brown rice flour and starch from different rice cultivars. Journal of Cereal Science. 58: 263-271. 